\title{
Open access web technology for mathematics learning in higher education*
}

\author{
Mari Carmen González-Videgaray ${ }^{1}$ \\ Rubén Romero-Ruiz ${ }^{2}$ \\ María del Rosario Hernández-Colón \\ Universidad Nacional Autónoma de México
}

DOI: http://dx.doi.org/10.17081/eduhum.17.29.1258

Recibido: 28 de enero de 2015

Aceptado: 21 de abril de 2015

\section{Tecnologías web de acceso abierto para el aprendizaje de matemáticas en la educación superior}

Key words:

Math anxiety, Web resource,

Free software, Video, Statistics.

Palabras clave:

Ansiedad matemática,

Recurso web, Software libre,

Video, Estadística.

\begin{abstract}
Problems with mathematics learning, "math anxiety" or "statistics anxiety" among university students can be avoided by using teaching strategies and technological tools. Besides personal suffering, low achievement in mathematics reduces terminal efficiency and decreases enrollment in careers related to science, technology and mathematics. This paper has two main goals: 1) to offer an organized inventory of open access web resources for math learning in higher education, and 2) to explore to what extent these resources are currently known and used by students and teachers. The first goal was accomplished by running a search in Google and then classifying resources. For the second, we conducted a survey among a sample of students $(n=487)$ and teachers $(n=60)$ from mathematics and engineering within the largest public university in Mexico. We categorized 15 high-quality web resources. Most of them are interactive simulations and computer algebra systems.
\end{abstract}

\begin{abstract}
Resumen
Los problemas en el aprendizaje de las matemáticas, como "ansiedad matemática" y "ansiedad estadística" pueden evitarse si se usan estrategias de enseñanza y herramientas tecnológicas. Además de un sufrimiento personal, el bajo rendimiento en matemáticas reduce la eficiencia terminal y decrementa la matrícula en carreras relacionadas con ciencia, tecnología y matemáticas. Este artículo tiene dos objetivos: 1) ofrecer un inventario organizado de recursos web de acceso abierto para aprender matemáticas en la universidad, y 2) explorar en qué medida estos recursos se usan actualmente entre alumnos y profesores. El primer objetivo se logró con un perfil de búsqueda en Google y una clasificación. Para el segundo, se condujo una encuesta en una muestra de estudiantes $(n=487)$ y maestros $(n=60)$ de matemáticas e ingeniería de la universidad más grande de México. Categorizamos 15 recursos web de alta calidad. La mayoría son simulaciones interactivas y sistemas de álgebra computacional.
\end{abstract}

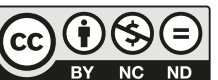

Referencia de este artículo (APA): González-Videgaray, M. C., Romero-Ruiz, R. \& Hernández-Coló, M. R. (2015). Open access web technology for mathematics learning in higher education. En Revista Educación y Humanismo, 17(29), 286-307. http://dx.doi. org/10.17081/eduhum.17.29.1258

* Artículo vinculado al proyecto "Vientos de cambio: Estrategias y buenas prácticas en el uso de ambientes virtuales para la educación superior" que hace parte del Programa de Apoyo a Proyectos para la Innovación y el Mejoramiento de la Enseñanza (PAPIME) de la Dirección de Asuntos del Personal Académico de la Universidad Nacional Autónoma de México.

1. Actuaria por la UNAM, Maestra en Educación y Doctora en Ingeniería Industrial por la Universidad Anáhuac. Realizando postdoctorado en Independencia Intelectual en la Universidad Anáhuac. mcgv@unam.mx

2. Ingeniero Eléctrico y Electrónico e Ingeniero en Computación por la UNAM, especialista en Gestión Informática y Maestro en Tecnologías de Información por la Universidad Anáhuac.

3. Licenciada en Enseñanza de Inglés por la UNAM, Maestra en Educación por la UNID, Doctorante en Investigación y Docencia por el CEPES. 


\section{Introduction}

Problems with mathematics learning have negative consequences among university students. These problems tend to undermine perception of achievement, lower self-esteem, diminish welfare within school, and affect career selection. Worse than that, there are even clinical states identified as "math anxiety" (Ashcraft, 2002; Geist, 2010; Meece, Wigfield and Eccles, 1990) and "statistics anxiety" (Chew and Dillon, 2014; Onwuegbuzie and Wilson, 2003; Zeidner, 1991), with their own form of diagnoses, etiology and treatment. These conditions have been reported in Mexico (Garcia-Santillan, MorenoGarcia, Carlos-Castro, Zamudio-Abdala and Garduño-Trejo, 2012; Tyteca, Parrilla and Martinez, 2013), and extend to undergraduates in mathematics and related areas (Cardoso Espinosa, 2012; Escalera-Chavez, Garcia-Santillan and Venegas-Martinez, 2013; Espinosa, Lopez and Mercado, 2012), where also students who have chosen this area of knowledge struggle with learning.

Personal suffering is not the only consequence of math learning problems. Besides all the above, scientific and technological knowl- edge construction depends greatly on math thinking (Andrade-Arechiga, Lopez and Pulido, 2013). Most scientific research has its basis on statistical theory. Rigorous mathematical reasoning is fundamental to propose new ideas in several scientific fields, and even qualitative research makes use of mathematical notions. Problems in math learning hinder student selection of science and technological careers, keeping them away from scientific research. So, the fact of being left behind in math learning has negative consequences for any country's development.

Mathematics learning is a global problem and Mexico is not the exception. At the end of 2013, PISA 2012 results were published, showing data that generates concern to our country. On one hand, Mexico decreased from 419 points in math in 2009, to 413 points in 2012. On the other hand, it was found that " $55 \%$ of Mexican students did not get the basic competence level in mathematics" (OCDE, 2013). These are clear indicators that math learning is still an important challenge. Within international statistics, Mexico is the last ranked country in the Organization for Economic Co-operation and Development (OECD), as shown in Figure 1.

Figure 1. Math average in PISA 2012, by country

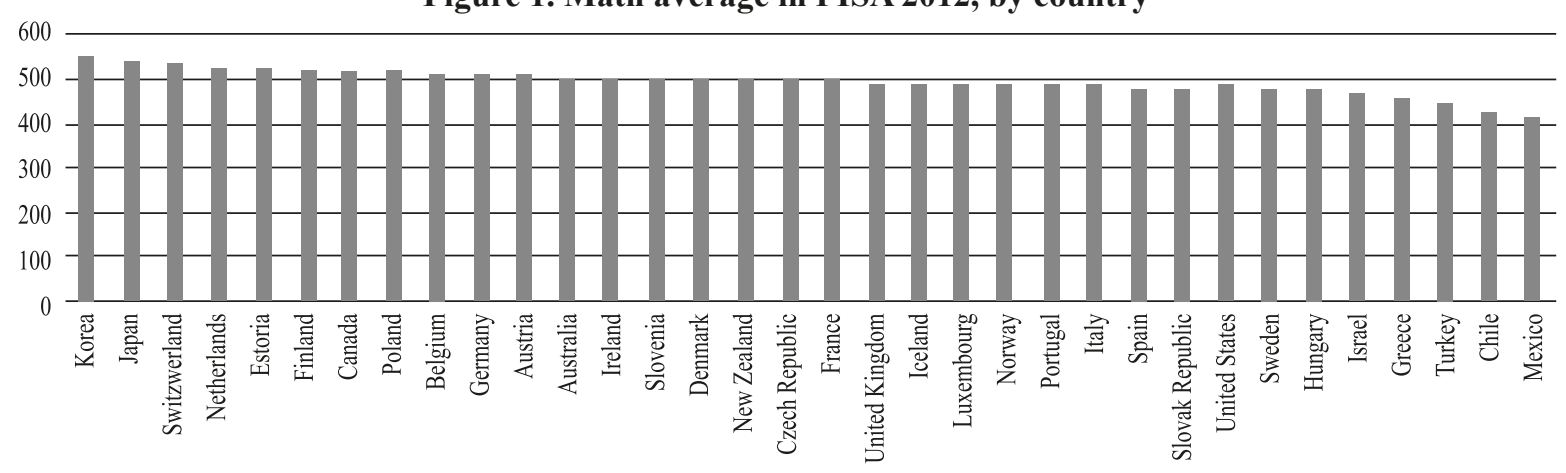

Source: (OECD, 2013) 
As a consequence of the above, only $0.4598 \%$ of the undergraduate students in 2011-2012 were matriculated in mathematics and statistics (ANUIES, 2013) in Mexico. Students commonly avoid this field of study because they anticipate strong difficulties with it. Henceforth, there are few professionals in this area and many university teachers belong to other related disciplines, but mathematics. This also has consequences in the teaching-learning process.

As this is a worldwide problem with different magnitudes and perspectives, there are multiple initiatives directed to attend this issue. Some of them involve the use of technology and, above all, new pedagogical ideas such as "active learning" (Freeman, et al., 2014), "flipping the classroom" (Alvarez, 2012; Rath \& Chung, 2013; Tucker, 2012) and "minimally invasive education" (Mitra \& Rana, 2001) can be found. The general approach of these views consists of having teachers' guidance and fostering students' practice in class, while leaving lectures and oral explanations to technological tools, such as videos or readings.

These pedagogical innovations require a substantial change of the teacher's role. She or he must be a kind of coach, capable of designing challenging and meaningful activities. A teacher as well must help with errors, guide through misconceptions, motivate, praise success, create learning environments where students' participation and discussions take place comfortably, and develop a pleasant learning experience for everyone.
As it was mentioned before, lectures, oral or written explanations, and repetitive exercises can be left to technology. In fact, some tools that might help do this work are already in the web. All the boring, stressing and intimidating aspects of learning can be lessen if students can get into them whenever and wherever they decide to do so. Learners can listen to clear explanations and good examples in comfortable and private spaces. Videos and animations can be stopped, rewound or fast-forwarded as needed. It is also possible to practice with a wide variety of exercises and try them out as many times as each student wishes or needs. As they are working alone, they will not feel ridiculous or silly in front of their teacher and classmates. They will not receive offensive commentaries or suffer from bullying.

For instance, Lloyd and Robertson (2012) have shown that screencasts or videos on how to use statistics software, are effective in teaching statistics to psychology students. Web tutorials, examples, lectures (Kay \& Kletskin, 2012) and animations (Taylor, Pountney, \& Baskett, 2008) tend to be perceived as attractive by learners. Garcia et al. (2014) propose the incorporation of algebra computer systems or CAS, not only to the learning processes, but to assessment as well. They suggest that this incorporation has a positive effect on developing valuable competences among students. Other authors (Shaffer, 2006) advise the use of immersive games or digital environments to teach math. These novelties can engage students and make learning more attractive. 
In fact, Garcia et al. (2014) point out that there has been a qualitative leap in math teaching in the last thirty years, within the European Community, thanks to new technologies, of course, but also to appropriate legislative frames. This is not Mexico's situation because most teachers continue using old teaching practices, even though the existence of an interesting and diverse offer of web resources designed to support math learning.

High cost is one of the barriers for the use of technology in class. However, due to recent worldwide initiatives as the Budapest Open Access Initiative (Open Society Institute, 2002), and the Free Software Foundation (Europe, 2014), among some others, there is a trend to offer high-quality open access web resources. They are usually free and their developers either receive grants or charge users for additional services such as consulting, customizing or expanding benefits.

In the case of mathematics learning, there are several open access web resources aimed to support learning. These resources are free, accessible via internet and easy to use, but their quality has to be assessed in order to use them appropriately. Once we have a categorized inventory of this kind of technology, it will be possible to study the extent they are currently being used. Thus, we propose two main hypotheses. The first one is that there is an interesting set of open access web resources with the potential to promote math learning. The second one is that university teachers and students are not yet conscious that the use of these tools can change math teaching and foster math learning.

So, this paper has two main goals. 1) To build an inventory of open access web resources that can help undergraduate mathematics learning in different ways. These resources are categorized by their kind of learning support, topics covered and language (English and/or Spanish).

2) To conduct a survey of the use of these resources among students and teachers from the most important public university of Mexico, Universidad Nacional Autonoma de Mexico or UNAM. We only selected students and teachers of mathematics and engineering, because we suppose that they should be best informed about these resources than people from other areas, and could, eventually, become intensive users of them. In other words, our results could probably be an over estimation of the characteristics of the population of all undergraduates.

Thus, our aim is to produce a synthetic -although probably not exhaustive- view of open access web resources intended to foster math learning. Even though these tools change and get better every day, the inventory could be used as a starting point to assess the possible benefits of this technology. Also we offer a panorama of how these resources are used in one of the largest and most important public universities in Mexico. 


\section{Material and Methods}

\subsection{Open Access Web Resources Review}

In order to locate open access web resources aimed to promote math learning, we ran the following search in Google: (online OR web OR digital OR internet OR computer) AND (learning OR teaching OR instruction OR knowledge) AND (math OR algebra OR calculus OR “differential equations" OR statistics OR geometry). The search was run in Spanish and in some variants of both languages (English and Spanish) as well.

To be selected in our inventory, web resources had to:

- Have an educational purpose.

- Offer undergraduate mathematical high-quality content.

- Be free and open access.

- Be functional within the web browser.

- Contain or show few and far between commercial ads.

- Show image and text balanced content.

- Be displayed in English and/or Spanish.

Once collected, web sites were categorized by:

- The kind of learning support: a) computer algebra system or CAS; b) interactive simulations; c) graphic visualizations; d) videos.

The topic covered: a) Algebra; b) Linear algebra; c) Numeric analysis; d) Calculus; e) Differential equations; f) Statistics; g) Analytic geometry; h) Applied mathematics; i) Discrete mathematics; j) Mathematics for computer science; k) Modeling and simulation; 1) Combinatorial optimization; m) Probability.
- Their language: a) English; b) Spanish; c) Both English and Spanish.

\subsection{Survey Sample Frame}

Survey sample sizes (Table 1) were determined based on population sizes during the autumn-winter cycle 2013-II at Facultad de Estudios Superiores Acatlán (Acatlan Faculty of Higher Studies), the largest of UNAM's multidisciplinary campi, located in the north zone of Mexico City. Students and teachers who were at the Faculty at that time and who were willing to respond answered the questionnaires. So, samples were not completely randomized.

We sampled the three careers that belong to the area of Mathematics and Engineering: Actuary, Civil Engineering and Applied Mathematics and Computing (MAC). Sample sizes were related to our practical possibilities. They provide a margin of about $6 \%$ of error and a confidence level of $90 \%$, which are acceptable for exploratory studies such as this.

Table 1. Study sample frame

\begin{tabular}{|l|c|c|c|c|}
\hline Major & $\begin{array}{c}\text { Student } \\
\text { population } \\
\text { size }\end{array}$ & $\begin{array}{c}\text { Student } \\
\text { sample } \\
\text { size }\end{array}$ & $\begin{array}{c}\text { Teacher } \\
\text { population } \\
\text { size }\end{array}$ & $\begin{array}{c}\text { Teacher } \\
\text { sample } \\
\text { size }\end{array}$ \\
\hline Actuary & 1061 & 160 & 82 & 20 \\
\hline $\begin{array}{l}\text { Civil } \\
\text { Engineering }\end{array}$ & 1084 & 160 & 104 & 20 \\
\hline MAC & 1386 & 167 & 99 & 20 \\
\hline Total & 3531 & 487 & 285 & 60 \\
\hline
\end{tabular}

\subsection{Questionnaires}

Two questionnaires were designed, one for students and one for teachers. The following data were collected: 
- Students: Career; semester; shift (morning or afternoon); sex; level of knowledge and use of web resources within a Likert scale with four options: $0=\mathrm{I}$ do not know it, $1=\mathrm{I}$ know it but I have never used it, 2 = I have used it from time to time, 3 = I use it frequently; other web resources that you want to add.

- Teachers: Career studied by teacher; subject(s) taught; level of knowledge and use of web resources within a Likert scale with four options: $0=\mathrm{I}$ do not know it, $1=\mathrm{I}$ know it but I have never used it, 2 = I have used it from time to time, 3 = I use it frequently; other web resources that you want to add.

\subsection{Survey Administration}

To administer the survey to students, we showed up in the classrooms and asked each teacher for permission. All of the teachers granted permission. Students attending class answered the printed version of the questionnaire.
As for teachers, they were asked to willingly respond the questionnaire. Even though participants remained anonymous, it is possible that teachers did not feel comfortable answering the questionnaire because the administrator could easily identify them.

\subsection{Survey Descriptive Statistics}

A database was built in Excel with the questionnaires' answers. Likert scale average was calculated for each web resource, within each sample group. These averages were presented in bar charts. A list of other suggested web resources was added to the end of the results.

\section{Results}

\subsection{Open Access Web Resources Review}

Fifteen open access math web resources with the characteristics explained in Section 2.1 fit the search profile. They are shown in Table 2 in alphabetical order, with their correspondent URL.

Table 2. Open access math web resources in alphabetical order

\begin{tabular}{|l|l|}
\hline \multicolumn{1}{|c|}{ Web Resource } & \multicolumn{1}{c|}{ URL } \\
\hline 1. Descartes & http://recursostic.educacion.es/descartes/web/ \\
\hline 2. GapMinder & http://www.gapminder.org \\
\hline 3. GeoGebra & http://www.geogebra.org/cms/ \\
\hline 4. Khan Academy & http://www.khanacademy.org/ \\
\hline 5. Math 2 Me & http://math2me.com/es/ \\
\hline 6. Maxima & http://maxima.sourceforge.net/ \\
\hline 7. MIT Mathlets & http://math.mit.edu/mathlets/ \\
\hline 8. PhET Interactive Simulations & http://phet.colorado.edu/ \\
\hline 9. Rice Virtual Lab in Statistics & http://onlinestatbook.com/rvls.html \\
\hline 10. The Number Empire & http://www.numberempire.com/ \\
\hline 11. OCW Videos & http://ocw.mit.edu/index.htm \\
\hline 12. Virtual Laboratories in Probability and Statistics & http://www.math.uah.edu/stat/ \\
\hline 13. Web Interface for Statistics Education & http://wise.cgu.edu/ \\
\hline 14. WIRIS & http://www.wiris.com/ \\
\hline 15. Wolfram Alpha & http://www.wolframalpha.com/ \\
\hline
\end{tabular}


Table 3. Web resources by their kind of learning support

\begin{tabular}{|l|c|c|c|c|}
\hline \multicolumn{1}{|c|}{ Web Resource } & CAS & Interactive Simulation & Graphic Visualization & Video \\
\hline 1. Descartes & $\mathrm{X}$ & & & \\
\hline 2. GapMinder & & & & \\
\hline 3. GeoGebra & $\mathrm{X}$ & & & \\
\hline 4. Khan Academy & & & & $\mathrm{X}$ \\
\hline 5. Math 2 me & & & & \\
\hline 6. Maxima & $\mathrm{X}$ & & & \\
\hline 7. MIT Mathlets & & $\mathrm{X}$ & & \\
\hline 8. PhET Interactive Simulations & & $\mathrm{X}$ & & \\
\hline 9. Rice Virtual Lab in Statistics & & $\mathrm{X}$ & & \\
\hline 10. The Number Empire & & $\mathrm{X}$ & & \\
\hline 11. OCW Videos & & & & \\
\hline 12. Virtual Laboratories in Probability and Statistics & & $\mathrm{X}$ & & \\
\hline 13. Web Interface for Statistics Education & & $\mathrm{X}$ & & 3 \\
\hline 14. WIRIS & $\mathrm{X}$ & & & \\
\hline 15. Wolfram Alpha & $\mathrm{X}$ & & & \\
\hline Total & 5 & 6 & & 1 \\
\hline
\end{tabular}

Table 4. Web resources by the topic(s) they cover

\begin{tabular}{|l|c|c|c|c|c|c|c|c|c|c|c|c|c|c|}
\hline \multicolumn{1}{|c|}{ Web Resource } & a & $\mathbf{b}$ & $\mathbf{c}$ & $\mathbf{d}$ & $\mathbf{e}$ & $\mathbf{f}$ & $\mathbf{g}$ & $\mathbf{h}$ & $\mathbf{i}$ & $\mathbf{j}$ & $\mathbf{k}$ & $\mathbf{~}$ & $\mathbf{m}$ & Total \\
\hline 1. Descartes & $\mathrm{X}$ & & & & & $\mathrm{X}$ & $\mathrm{X}$ & $\mathrm{X}$ & & & & & $\mathrm{X}$ & 5 \\
\hline 2. GapMinder & & & & & & $\mathrm{X}$ & & & & & & & & 1 \\
\hline 3. GeoGebra & $\mathrm{X}$ & & & & & & $\mathrm{X}$ & & & & & & & 2 \\
\hline 4. Khan Academy & $\mathrm{X}$ & $\mathrm{X}$ & & $\mathrm{X}$ & $\mathrm{X}$ & $\mathrm{X}$ & $\mathrm{X}$ & & & & & & $\mathrm{X}$ & 7 \\
\hline 5. Math 2 me & $\mathrm{X}$ & & & $\mathrm{X}$ & & $\mathrm{X}$ & $\mathrm{X}$ & & & & & & $\mathrm{X}$ & 5 \\
\hline 6. Maxima & $\mathrm{X}$ & $\mathrm{X}$ & $\mathrm{X}$ & $\mathrm{X}$ & $\mathrm{X}$ & $\mathrm{X}$ & $\mathrm{X}$ & & & & & & $\mathrm{X}$ & 8 \\
\hline 7. MIT Mathlets & & & & & $\mathrm{X}$ & & & & & & & & & 1 \\
\hline 8. PhET Interactive Simulations & & & & & & $\mathrm{X}$ & $\mathrm{X}$ & & & & & & & 2 \\
\hline 9. Rice Virtual Lab in Statistics & & & & & & $\mathrm{X}$ & & & & & & & & 1 \\
\hline 10. The Number Empire & $\mathrm{X}$ & $\mathrm{X}$ & & $\mathrm{X}$ & & $\mathrm{X}$ & & & & & & & & 4 \\
\hline 11. OCW Videos & $\mathrm{X}$ & $\mathrm{X}$ & $\mathrm{X}$ & $\mathrm{X}$ & $\mathrm{X}$ & $\mathrm{X}$ & & $\mathrm{X}$ & $\mathrm{X}$ & $\mathrm{X}$ & $\mathrm{X}$ & $\mathrm{X}$ & $\mathrm{X}$ & 12 \\
\hline 12. Virtual Laboratories in Probability and Statistics & & & & & & $\mathrm{X}$ & & & & & & & $\mathrm{X}$ & 2 \\
\hline 13. Web Interface for Statistics Education & & & & $\mathrm{X}$ & & & & & & & & & & 1 \\
\hline 14. WIRIS & $\mathrm{X}$ & $\mathrm{X}$ & $\mathrm{X}$ & $\mathrm{X}$ & $\mathrm{X}$ & $\mathrm{X}$ & $\mathrm{X}$ & & & & & & $\mathrm{X}$ & 8 \\
\hline 15. Wolfram Alpha & $\mathrm{X}$ & $\mathrm{X}$ & $\mathrm{X}$ & $\mathrm{X}$ & $\mathrm{X}$ & $\mathrm{X}$ & $\mathrm{X}$ & & & & & & $\mathrm{X}$ & 8 \\
\hline Total & 9 & 6 & 4 & 8 & 6 & 12 & 8 & 2 & 1 & 1 & 1 & 1 & 8 & \\
\hline
\end{tabular}

a) Algebra; b) Linear algebra; c) Numeric analysis; d) Calculus; e) Differential equations; f) Statistics; g) Analytic geometry; h) Applied mathematics; i) Discrete mathematics; j) Mathematics for computer science; k) Modeling and Simulation; 1) Combinatorial optimization; m) Probability 
Web resources were classified by their kind of learning support and organized in Table 3. Most of them are interactive simulations and CAS.

Table 4 shows web resources organized by the topics they cover. OCW Videos cover more topics than other resources, followed by three CAS: Maxima, WIRIS and Wolfram Alpha. In turn, Statistics is the most covered topic, followed by Algebra.

Finally, we present the categorization by language, where we can see that there are two web resources in Spanish, five in English and Spanish, and eight in English.

Table 5. Web resources by language

\begin{tabular}{|l|c|c|c|}
\hline \multicolumn{1}{|c|}{$\begin{array}{c}\text { Web } \\
\text { Resource }\end{array}$} & Spanish & $\begin{array}{c}\text { English \& } \\
\text { Spanish }\end{array}$ & English \\
\hline 1. Descartes & $\mathrm{X}$ & & \\
\hline 2. GapMinder & & & $\mathrm{X}$ \\
\hline 3. GeoGebra & & $\mathrm{X}$ & \\
\hline 4. Khan Academy & $\mathrm{X}$ & & \\
\hline 5. Math 2 me & & & $\mathrm{X}$ \\
\hline 6. Maxima & & & $\mathrm{X}$ \\
\hline 7. MIT Mathlets & & $\mathrm{X}$ & \\
\hline $\begin{array}{l}\text { 8. PhET Interactive } \\
\text { Simulations }\end{array}$ & & & $\mathrm{X}$ \\
\hline $\begin{array}{l}\text { 9. Rice Virtual Lab in } \\
\text { Statistics }\end{array}$ & & & $\mathrm{X}$ \\
\hline 10. The Number Empire & & $\mathrm{X}$ & \\
\hline 11. OCW Videos & & & $\mathrm{X}$ \\
\hline $\begin{array}{l}\text { 12. Virtual Laboratories in } \\
\text { Probability and Statistics }\end{array}$ & & & $\mathrm{X}$ \\
\hline $\begin{array}{l}\text { 13. Web Interface for } \\
\text { Statistics Education }\end{array}$ & & & $\mathrm{X}$ \\
\hline 14. WIRIS & & $\mathrm{X}$ & \\
\hline 15. Wolfram Alpha & & 5 & 8 \\
\hline Total & 2 & & \\
\hline
\end{tabular}

\subsection{Student's Survey}

As Figure 2 shows, Actuary students are relatively familiarized with Wolfram Alpha and somewhat less with GeoGebra, Maxima and Math 2 me. The other web resources are practically unknown to them; they have indexes near zero.

Regarding Civil Engineering students, they practically do not recognize nor use any of the web resources listed (Figure 3).

Within MAC career students' results, Wolfram Alpha and GeoGebra stand out (Figure 4). The rest of the resources present low values.

\subsection{Teacher's Survey}

According to Figure 5, Actuary teachers are somewhat familiarized with GeoGebra and Wolfram Alpha. The third more known value corresponds to Descartes.

Civil Engineering teachers report, like the students' case, that they are unaware of almost all math web resources (Figure 6).

Finally, MAC teachers know about Wolfram Alpha and GeoGebra (Figure 7). They practically do not know or use other resources.

\subsection{Other Resources Suggested by Respon-} dents

With respect to the open question where they could add some other web resources which can contribute to mathematics learning, participants 
Figure 2. Average knowledge of math web resources of Actuary students

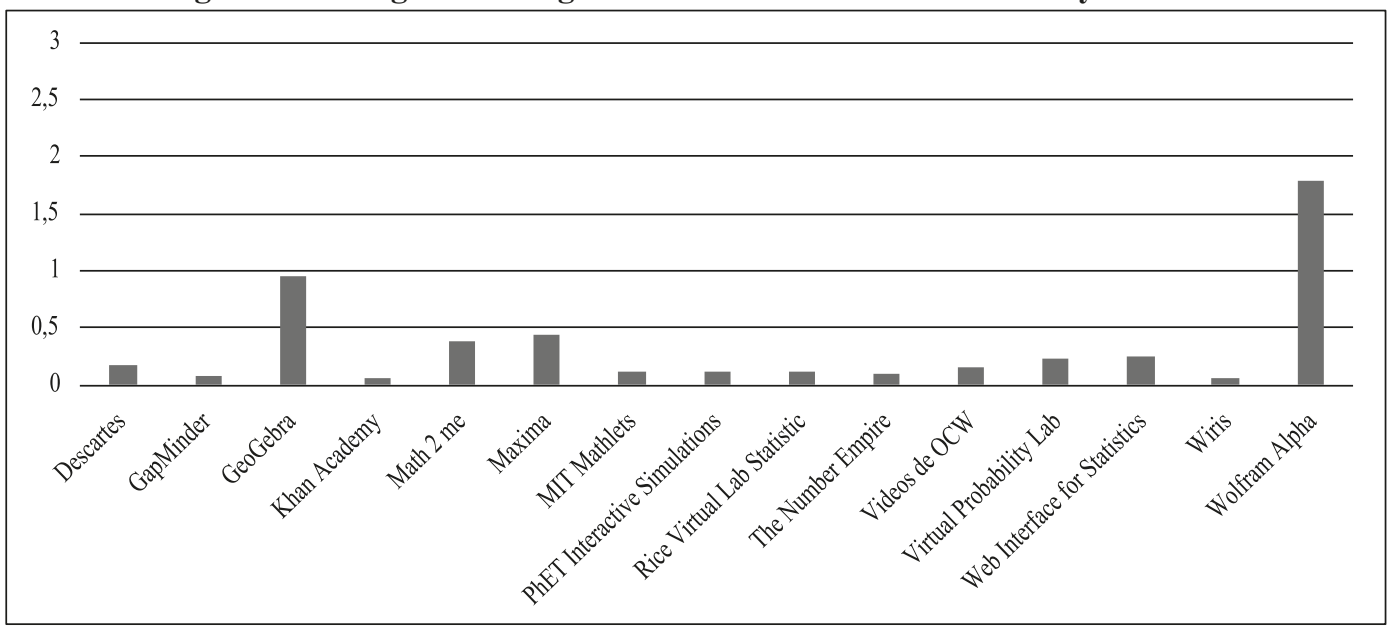

Figure 3. Average knowledge of math web resources of Civil Engineering students

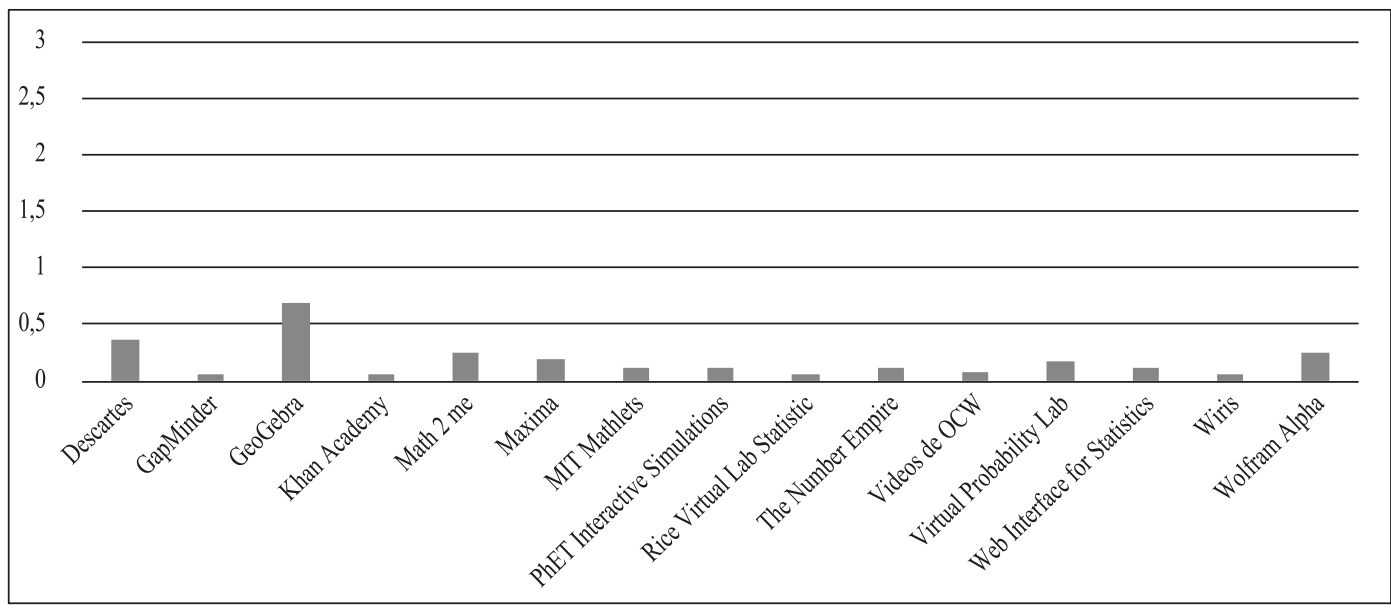

Figure 4. Average knowledge of math web resources of MAC students

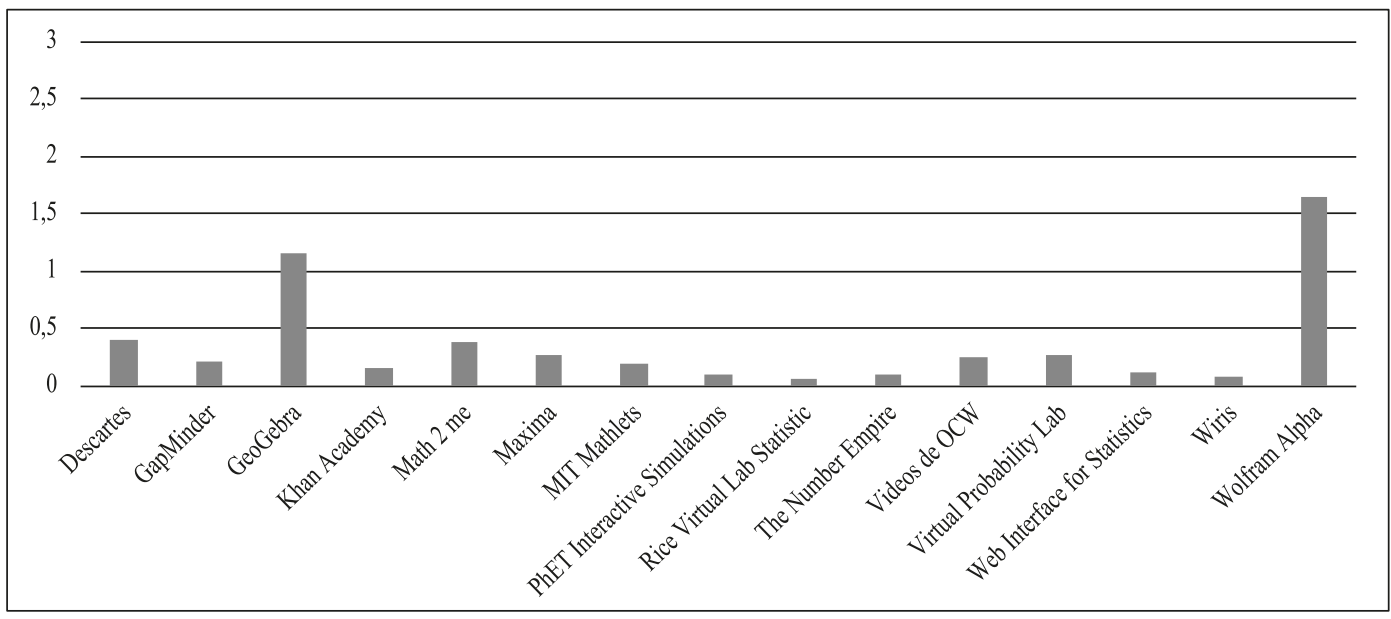


Figure 5. Average knowledge of math web resources of Actuary teachers

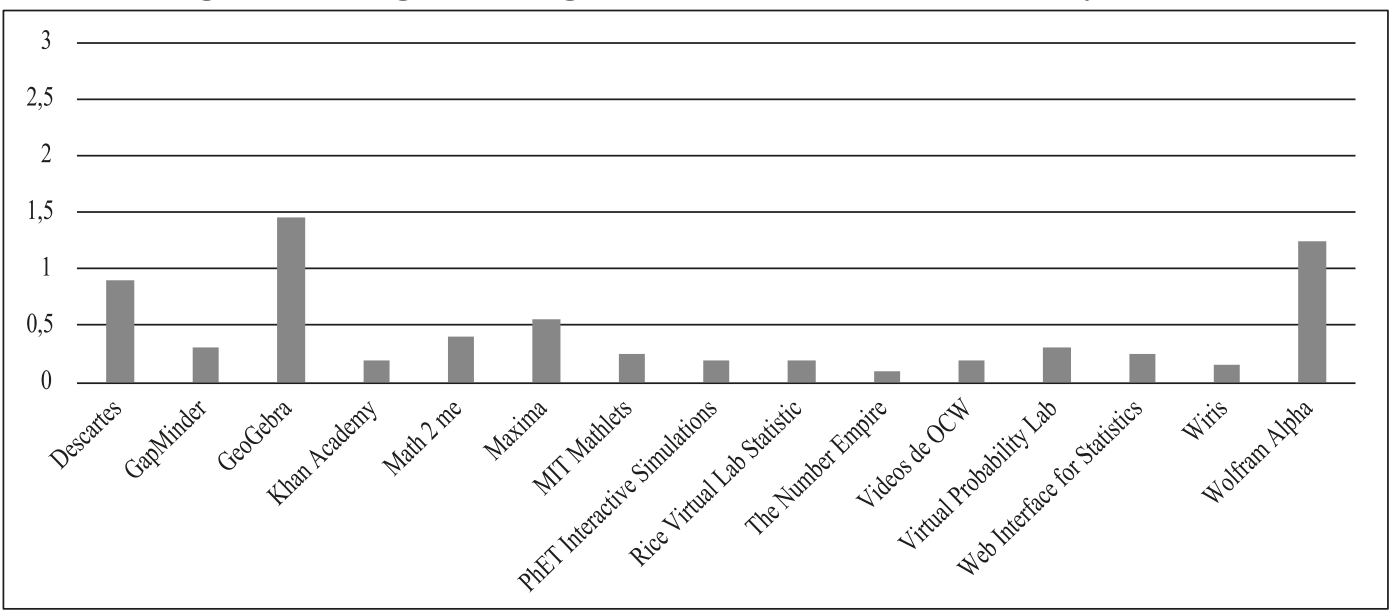

Figure 6. Average knowledge of math web resources of Civil Engineering teachers

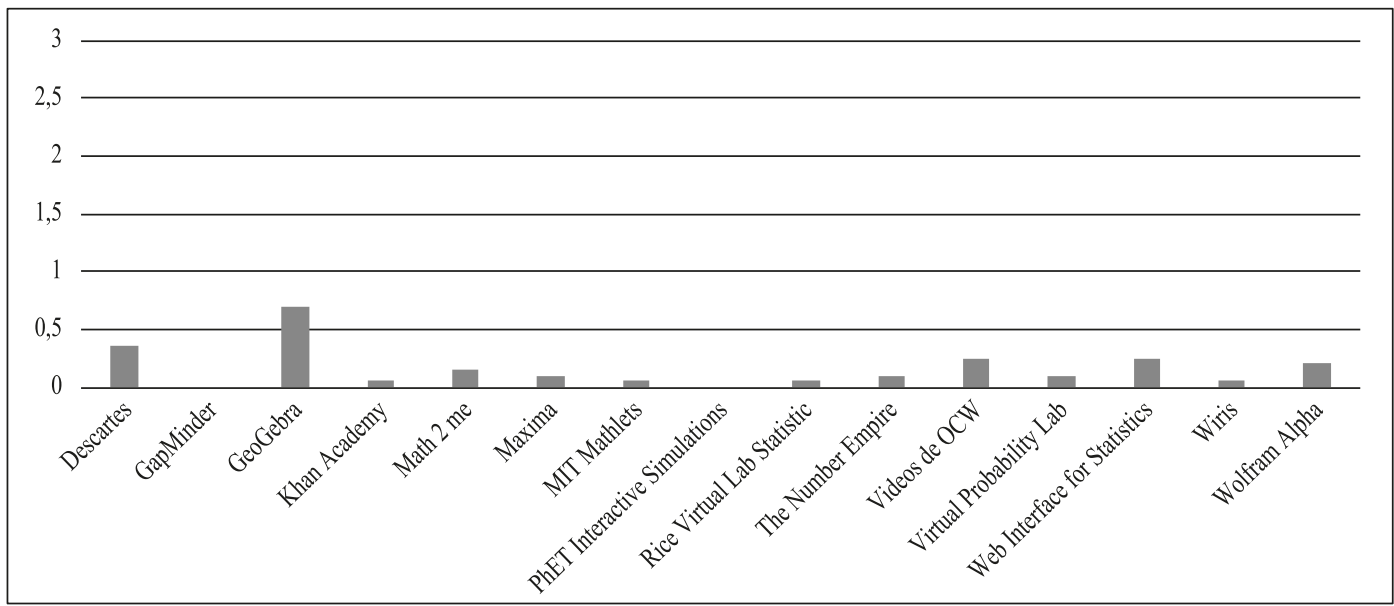

Figure 7. Average knowledge of math web resources of MAC teachers

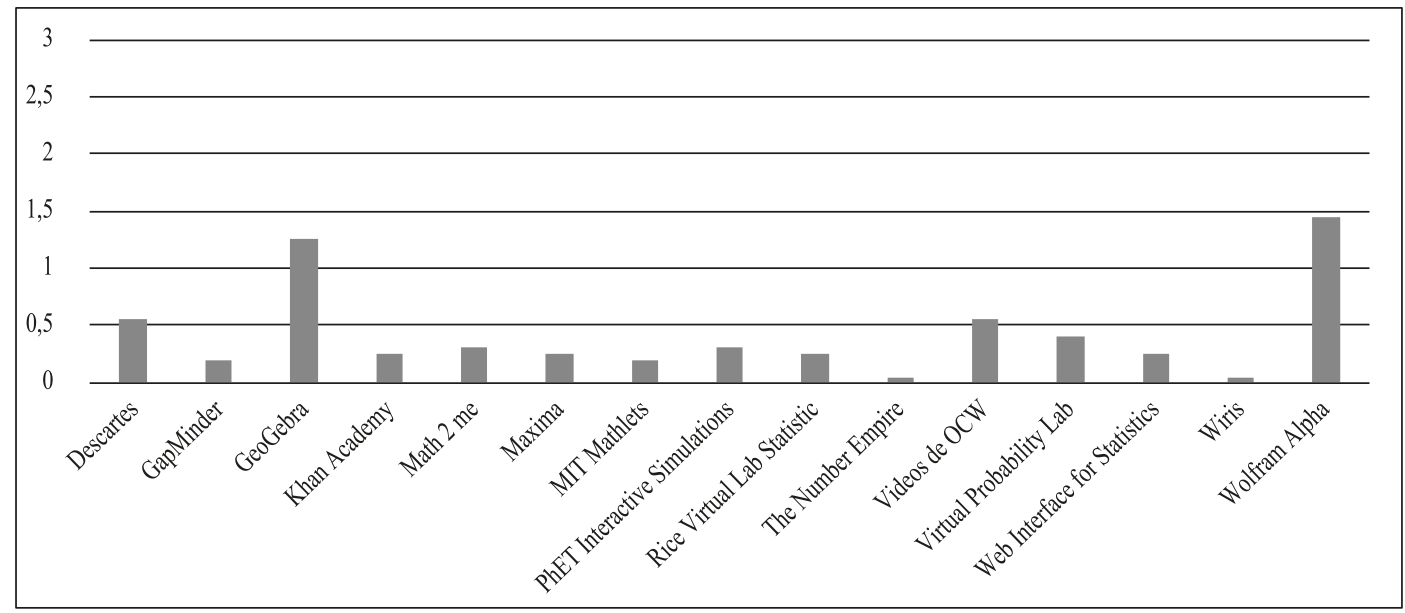


mentioned: Octave, a high-level interpreted language, primarily intended for numerical computations; Cinderella, an interactive geometry software; self-teaching tools developed by UNAM; Scilab, an open source software for numerical computation; Winplot, a general-purpose plotting utility, which can draw (and animate) curves and surfaces presented in a variety of formats; Mathcad, proprietary software for engineering calculations; Scientific Workplace, a commercial mathematical word processor; Statgraphics Online, a commercial statistical package that runs within a web browser; EViews, solutions for forecasting, econometrics and simulation; GrafEq, a program for producing graphs of implicit equations and inequalities; NumPy, a package for scientific computing with Python; SciPy, a Python-based ecosystem of open-source software for mathematics, science, and engineering; SymPy, a Python library for symbolic mathematics; Scholastic, with solutions for prime mathematics; and some other educational software products as Prezi or Hot Potatoes.

\section{Discussion}

\subsection{Open Access Web Resources Inventory}

In order to accomplish one of the objectives of this paper, and with the help of our search strategy, we built an open access math web resources inventory. It includes fifteen high-quality items, useful for learning mathematics in higher education, Most of them are interactive simulations and CAS, and the rest are videos and graphic visualizations. This is really interesting because all of them can support the idea of active math learning as stated in Freeman, et al. (2014). Development of HTML5, Java applets and new programming languages has contributed to the creation of this kind of resources.

There is an almost natural relationship between interactive simulations and mathematics. Simulations are based on mathematical probabilistic processes. Maybe this is due to the fact that most open access web math resources are interactive simulations. Besides, math learning implies comprehension and practice, and both can be promoted by engaging simulations, where the student can experiment, devise causal relationships and even play with mathematical artifacts. Some studies (Ray, 2013; Siddique, Ling, Roberson, Xu \& Geng, 2013) report that interactive simulations can be effective in promoting math learning and high order thinking, but more work is needed in this area.

The use of CAS in math teaching is an important-and somewhat polemic-issue. As it can be seen, five open access CAS, which are very useful and well designed, were found. Recently, Marshall et al. (2012, p.423) stated that "emerging technologies such as computer algebra systems (CAS) brought with them the potential to shape new directions in the teaching and learning of mathematics". Part of our study is directed precisely to see if these new teaching directions are being considered in UNAM FES Acatlan.

In particular, Wolfram Alpha is, as indicated in its web site, a very powerful "computational 
knowledge engine". It can solve analytic equations, not only numerical operations, with a very easy and intuitive notation, from arithmetic operations and basic algebra, to differential equations, everything within a web browser. It displays solutions, as well as the required processes to get to them. It creates nice and useful graphics. It even works in an iPhone, paying a small fee for the service. All these advantages, make us reflect on our actual teaching and learning processes. As a result, we need to give a serious thought to the idea of including Wolfram Alpha in our daily practice. Even though this might sound appropriate or even needed, it is an idea that requires further discussion.

Regarding other resources, it is remarkable that $\mathrm{OCW}$ and Khan Academy provide videos of almost every math undergraduate topic. In the first case, we can find complete lectures, one or two hours long, with speakers of the highest quality at the Massachusetts Institute of Technology. It is a really nice opportunity to take some lessons directly from the very authors of classic textbooks, such as Linear Algebra with Professor Gilbert Strang. In the second case, Salman Khan has developed a novel teaching approach, with short and clear videos of each particular topic. This kind of presentation is consistent with the idea of "learning objects" and their desirable properties (Gonzalez-Videgaray, HernandezZamora \& Del-Rio-Martinez, 2009), since they are brief and self-contained. This allows students to select the exact video they need to fulfill a certain goal, and to watch it many times. The oppor- tunity to watch it as much as needed, provides the students with extra practice, and in some cases, this might help avoid exasperating the teacher or suffering bullying from other classmates. Besides, learners can watch them whenever and wherever they want (Parslow, 2012), in a private and comfortable environment, from a computer or a mobile device. Another advantage of this kind of videos is that they can reach a large number of students (Heckel, Bach, Richert \& Jeschke, 2012), which is generally the case at Mexican public universities.

Maybe a special instance within web resources is GapMinder, an initiative of Hans Rosling, a Swedish professor of global health. He constructed a site that combines statistics with dynamic animation, beauty and social awareness. He provides visualizations of important country indicators, making easy to identify causal relationships (Lodha, Gunawardane, Middleton \& Crow, 2009) and their behavior through time. This site presents real and significant data, which can contribute to engage students in statistics learning. Rosling's software, called Trendalyzer, is now used by the most important statistics organism in Mexico to display demographic data: the National Institute of Statistics and Geography (INEGI, 2014). Even though trend animation seems to be exciting and enjoyable for students, it is possible that sometimes they lead to interpretation errors (Robertson, Fernandez, Fisher, Lee \& Stasko, 2008). These ideas deserve to be further researched. 
We found that there are web resources for the most common topics of undergraduate mathematics programs. So, we definitively believe that it is possible to combine them with other teaching strategies. In particular, OCW Videos cover almost all the topics that are usually found in a mathematics program. This is understandable because they intend "to publish all of our course materials online and make them widely available to everyone", as it is written in their web site (MIT, 2014). This is splendid, but as the videos are actual lectures, anyone could argue that they are not technically nor pedagogically designed to be watched via internet with a learning objective in mind. In spite of that, these resources have benefited learners, including "informal learners" and "independent learners" (Carson, Kanchanaraksa, Gooding, Mulder \& Schuwer, 2012).

The results showed that the topic with more available web resources is statistics. Our findings are consistent with the meta-analysis of Sosa et al. (2011) and with Symanzik \& Vukasinovic (2003), who consider that the high number of web resources about statistics is due to the large offering of data, statistics calculators, software and other internet tools. This, in turn, can be explained because this topic is included in most majors and careers. One reason of this inclusion is that this subject is required to learn about research techniques and methods, especially quantitative research. Another reason is, perhaps, that statistical thinking is an important skill essential to be a more prepared and complete citizen nowadays. As Australians say in their Statistical Declaration (Australian Bureau of Statistics, 2008): "The ability to understand and evaluate statistics that permeate our daily lives is an essential building block of basic numeracy skills. Improving statistical skills should be part of the curriculum in all levels of education, as well as in training programs in government, business and the wider community". It is remarkable that in the entire world a big effort has been done to improve statistical literacy (Schield, 2004). In Latin America and Spain there is important research on this issue, conducted by Batanero (2004) and some others.

Statistics is followed by algebra, which is not surprising because it is also part of many curricula in higher education. Since 2003, an effective performance in algebra through a combination of self-regulated learning and the use of CAS has been reported (Kramarski \& Hirsch, 2003) and, of course, CAS were designed to precisely make improvements on this topic. Today they even have a greater potentiality. Algebra is considered a "foreign language" to some students. They struggle with mysterious characters that represent numbers, but simultaneously, can be operated as numbers considering certain rules that are usually memorized without comprehending them. Certain students write numbers instead of letters, in order to get a better understanding, so it is now challenging to have an "algebraic calculator" for a change.

In respect of the languages in which the web 
resources are available, it was a pleasant surprise to find that there are two in Spanish and five in English and Spanish. The rest are in English and that is in many cases an obstacle for some potential users in Latin America. The Mexican government has made some efforts to include English as a mandatory subject in public schools, but it will be taught in all public schools until 2018 (La Redaccion, 2011). However, within our study, it is important to point out that all mathematics and engineering university students must display an English proficiency diploma as a requirement to obtain their B.A. degrees; unfortunately, many undergraduate students do not get their language diplomas on time. By the time these students finish school and incorporate to real life jobs, they cannot make any improvements in their professional practice because they have not fulfilled this requirement.

Several OCW Videos have Spanish subtitles. Statistical machine translation continues its development (Koehn, 2010) and it surely will help with this matter soon. Besides, Carlos Slim -Mexican entrepreneur and one of the wealthiest men in the world-is now supporting the Spanish translation of Salman Khan videos (Fundacion Carlos Slim, 2013). Considering this, it is possible now to really flip our classroom's dynamic, by leaving some of the traditional blackboard explanations to these videos. Obviously, this can only be possible if there is access to computers and internet. About $38.4 \%$ of the population in Mexico (Grupo del Banco Mundial, 2014) has this opportunity, and almost all of undergraduate students are considered in this percentage.
In addition to our inventory, the survey respondents suggested some interesting resources. We are conscious that our search profile took only a still photograph and captured just a few items of a richer world of possibilities. More and better math web resources are being developed constantly and some of them are open access. Maybe it is important to be aware of this and stay permanently updated. This represents additional work for both teachers and students and implies to develop a lifelong learning capacity, which seems to be a hallmark of the $21^{\text {st }}$ century.

We can conclude by mentioning that the inventory of math web resources with open access is rich, diverse, useful and interesting. We must not forget that there are a lot of commercial or proprietary resources that can also help promote mathematics learning, but the existence of free and accessible tools, available through internet, represents good news to our country and to Spanish-speaking countries in general.

\subsection{Use of Web Resources}

Once we have reviewed the inventory of valuable web resources to foster math learning, it is advisable to analyze how they are used in our universities, if so. Survey results suggest that, despite the variety of tools such as CAS, video lectures, short video explanations, interactions, visualization and animations, all of them free and easily available, there is little knowledge about them amongst teachers and students. Therefore, their use is very limited, even in mathematics and engineering careers, where one could expect to be more acquainted with them. 
It seems that students and teachers from Actuary and Mathematic careers are somewhat more familiarized with these resources than those from Civil Engineering, possibly because the first ones make a more intensive use of computers in their scholar work. Data does not provide enough evidence of a significant difference between teachers' and students' knowledge, as all items got low values.

Wolfram Alpha and GeoGebra stand slightly over other resources. As we noted before, Wolfram Alpha is a powerful knowledge engine, capable of doing symbolic operations with simple or partial information. As for the second, its acquaintance is possible due to the fact that our Faculty hosts the GeoGebra Institute of the UNAM (GeoGebra, 2014), but we then would have expected much more. This resource is an interactive free CAS, with thousands of free resources and learning materials, from basic to higher education, and there are reports about its suitability to support learning in combination with interactive white blackboards (Lavicza \& Papp-Varga, 2010) Cambridge, England [PappVarga, Z] Eotvos Lorand Univ, Dept Comp Sci, Budapest, Hungary\&\#xD; Lavicza, Zsolt (reprint author. Students and teachers at our Faculty are aware of its existence but do not use it.

It is clear that open access math web resources are poorly known and used within our Faculty. There can be several reasons that might explain these findings. One possibility is that teachers are using, instead, commercial tools designed to promote math learning. However, as far as we could establish by asking the cor- respondent department, there are no software licenses or agreements of this kind in the Faculty. Of course, it is possible - not at all desirable- that some teachers and students are using illegal copies, but this practice would be eliminated with the use of open access web resources.

Marshall et al. (2012) have stated that commercial cost and difficult syntax are important obstacles for the use of CAS. It is interesting to see that both problems are practically inexistent in Wolfram Alpha, which is free and allows a very intuitive way of writing formulas. For instance, it is possible to type "derive $\mathrm{x} 2+4 \mathrm{x}+4$ " to instantly get the result shown in figure 8 ; or "plot normal" to watch the screen displayed in Figure 9. This can explain why this web resource is the most used by students. If one wants to see step-by-step solutions, a Pro version is offered with a cost of $\$ 4.99$ USD per month or \$45 USD per year.

Figure 8. Derivative produced with Wolfram Derivative: Alpha

$\frac{d}{d x}\left(x^{2}+4 x+4\right)=2(x+2)$

Figure 9. Normal distribution variants elaborated Result: with Wolfram Alpha

$\frac{e^{-\frac{(x-\mu)^{2}}{2 \sigma^{2}}}}{\sqrt{2 \pi} \sigma} \approx \frac{0.398942 \times 2.71828^{-\frac{0.5(x-\mu)^{2}}{\sigma^{2}}}}{\sigma}$

Plots for typical parameters:

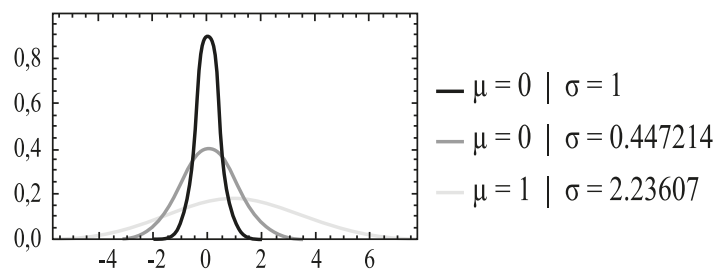


Our results could also be linked to a general lack of information literacy (American Library Association, 1989) at the university. De Arenas et al. (2004, p.459) have reported deficiencies in this kind of literacy in Mexico and Spain, that they attribute "to educational bureaucracy, to anachronistic ways of teaching that validate reliance on note-taking by students, on textbookbased learning and on absorbing outdated information". Maybe teachers and learners are still relying on traditional practices and have not been interested in looking for new alternatives, or maybe they have not developed good search strategies that could help them find these specific resources. As Rowlands et al. (2008) say, the idea that digital natives and Google generation are expert searchers is a "dangerous myth" and there is "increasing evidence that students do not use technology effectively when they conduct research or communicate" (Katz, 2013, p.4). Possibly, even when they are conscious of their problems with mathematics, they do not consider it a global problem and neither that there are interesting learning alternatives within their reach on the web.

Besides, our findings can also be related to deficiencies of digital literacy as established by Ng (2012): "Unless taught explicitly to use other (educational) technologies, it is unlikely that digital natives would think about educational technologies". Ng points out that students can easily manage technologies if they are aware of them and want to include them in their learning process, but they do not look intentionally for them. So, if teachers do not know about these resources, it is almost impossible that students do.

Another possibility is that mathematics teachers are slowly getting aware of the potential advantages of these resources. Maybe there is some resistance to change and certain fear of using these tools. We heard recently a math teacher stating the importance of knowing how to solve a square root manually. He said that if a student were in a desert island, how would she or he solve a square root without a computer? The question we make is, would a student facing such circumstance be interested in solving square roots? Maybe the central discussion point is related to the concern expressed by Reed, Drijvers \& Kirschner (2010, p.1): "students may learn only to manipulate the tools rather than master the underlying concepts". Of course, the main goal of math learning is that the student masters concepts, develops skills and feels comfortable with mathematical thinking. Probably deeper work is required to show how web tools can effectively foster math learning before teachers actually adopt them. These studies will let them realize the potential benefits that employing mathematical computer tools in a class, have.

Within the course of this research, we had the opportunity to see students' and teachers' reactions to the survey. Some students took photographs of the questionnaire, in order to store the resources inventory for subsequent use. Some wondered about so many sites they did not know. 
Some others were worried because they did not want their teachers to be conscious of this kind of tools: students currently use them -particularly Wolfram Alpha- to solve homework and they want the teacher to think that they are still working with pencil and paper. In fact, they seemed a bit upset with the research and the researchers. Besides, several of them said they have passed exams thanks to Khan Academy, and not thanks to the teachers' classes.

Teachers, in turn, took a defensive position. They thought it was a kind of test or an assessment on their actualization. Some of them were curious, but some others were worried for not knowing the web resources listed in the questionnaire. It will be interesting to apply the survey again soon and see if there are any changes. Also, more research is needed on the teacher's perspective concerning these web resources uses.

\subsection{Limitations of our study}

Our study was circumscribed to one campus of the most important public universities in Mexico; it would be valuable to replicate it in other campi and considering other similar careers. The questionnaires could be enriched with some of the resources mentioned by the respondents and with a more exhaustive search. Our research was mainly quantitative and did not consider the teachers' and students' positions on this subject.

\subsection{Conclusions}

Our study confirms the assertion of Marshall et al. (2012, p.423): "In spite of the fact that a growing number of international studies have demonstrated that CAS-based instruction has the potential to positively influence the teaching and learning of mathematics at various levels of the education system, CAS has not been widely implemented in schools and higher education institutions". This seems to be true not only about CAS, but other videos, interactions, animations and simulations for undergraduate math learning in the web, at the UNAM and probably at some other universities in our country.

We have seen that there is a large amount of varied, attractive and useful open access web resources that can promote undergraduate math learning, especially in English but also in Spanish. In order to exploit this opportunity, there are some pre-requisites. We must promote information and digital literacies, so every teacher and student can find effective tools to support math learning. This is very important because there are always novelties, so one must research for them every now and then, to stay updated in this subject. Besides, it is indispensable to be capable of assessing and selecting the best tools for each requirement.

It is also essential, for our teachers and students, to achieve proficiency in English as a second language. This will open up the range of possibilities and allow a more active participation in learning. Of course, it is also desirable that efforts should continue to translate or subtitle existing resources, besides producing them in Spanish. 
In any case, it is imperative to subject to academic discussion the use of these web resources within math undergraduate education processes. With more than twenty years of experience, Garcia et al. (2014) propose a model for the incorporation of CAS to the math learning process. This model asks for three requirements: a) integrate CAS to all learning and assessment activities, b) motivate students to create tools and problem solutions of their own with the CAS, and c) promote the use of CAS out of the specific math subject, for instance, to solve chemistry or physics problems. Probably, the use of CAS in assessments and tests continues to be the most polemic issue (Marshall, et al., 2012) among teachers. More discussion and research is needed about it.

The kind of dynamic visualizations offered by these resources can beyond doubt help to improve the experience of math learning, because they contrive to a better comprehension, remembrance, inspiration and motivation in students (Burewicz \& Miranowicz, 2002). Besides, it seems that there is no way back in the use of these tools, which are each day more attractive, efficient, powerful and easy to use.

We plan to continue studying why these web resources are not properly disseminated, how they are currently used, and what should be done to promote their intelligent and critical use. We need to reflect on the implications of this use not only for teaching strategies, but for the selection of contents that should be taught, as well. In other words, these web resources compel us to evaluate how we should teach, but also what we should teach in mathematics. Maybe we must reduce procedure and mechanical aspects in order to enhance reflection, approach and problem solving, as well as real significant applications of math skills.

\section{References}

Alvarez, B. (2012). Flipping the Classroom: Homework in Class, Lessons at Home. Education Digest: Essential Readings Condensed for Quick Review, 77(8), 1821.

American Library Association (1989). Information Literacy Competency Standards for Higher Education. Retrieved 23/05, 2014. Andrade-Arechiga, M., Lopez, G. \& Pulido, J. (2013). Mathematics Education and Information Technologies in Emerging Economies. Creative Education, 4, 40.

Anuies (2013). Anuario Estadístico de Educación Superior. Retrieved 19/05, 2014, from http://www.anuies.mx/content. php?varSectionID=166

Ashcraft, M. H. (2002). Math anxiety: Personal, educational, and cognitive consequences. Current Directions in Psychological Science, 11(5), 181-185.

Australian Bureau of Statistics (2008). NatStats08 Statistical Declaration - Working Together for an Informed Australia in the 21st Century. Retrieved 20/05, 2014, from http://www.nss.gov.au/nss/home. nsf/NSS/BF58B79DECE73EDFCA2575 0C0080346F?opendocument 
Batanero, C. (2004). Los retos de la cultura estadística. Yupana, 1(1), 27-37.

Burewicz, A. \& Miranowicz, N. (2002). Categorization of visualization tools in aspects of chemical research and education. [Article]. International Journal of Quantum Chemistry, 88(5), 549-563.

Cardoso Espinosa, E. O. (2012). Evaluación sobre los perfiles de ingreso de los alumnos de los posgrados de administración: actitudes y experiencias hacia las matemáticas. Universidad de Granada, 16(1).

Carson, S., Kanchanaraksa, S., Gooding, I., Mulder, F. \& Schuwer, R. (2012). Impact of OpenCourseWare Publication on Higher Education Participation and Student Recruitment. International Review of Research in Open and Distance Learning, 13(4), 19-32.

Chew, P. K. \& Dillon, D. B. (2014). Statistics Anxiety Update Refining the Construct and Recommendations for a New Research Agenda. Perspectives on Psychological Science, 9(2), 196-208.

De Arenas, J. L., Rodriguez, J. V., Gomez, J. A. \& Arenas, M. (2004). Information literacy: implications for Mexican and Spanish university students. Library Review, 53(9), 451-460.

Escalera-Chavez, M., Garcia-Santillan, A. \& Venegas-Martinez, F. (2013). Attitude towards Statistics differs among public and private universities? International Journal of Mathematical Archive (IJMA), 4(5).
Espinosa, E. O. C., Lopez, E. A. V. \& Mercado, M. T. C. (2012). Diagnóstico sobre las actitudes hacia las Matemáticas del estudiantado que inicia sus estudios en tres posgrados en Administración de Empresas. Revista Electrónica Educare, 16(2), 237-253.

Europe, F. S. F. (2014). FSFE. Retrieved 25/06, 2014, from https://fsfe.org/

Freeman, S., Eddy, S. L., Mcdonough, M., Smith, M. K., Okoroafor, N., Jordt, H., et al. (2014). Active learning increases student performance in science, engineering, and mathematics. Proceedings of the National Academy of Sciences, 111(23), 8410-8415.

Fundacion Carlos Slim (2013). Alianza Fundación Carlos Slim y Khan Academy. Retrieved 19/05, 2014, from http://www.carlosslim.com/responsabilidad_kahan.html

Garcia-Santillan, A., Moreno-Garcia, E., Carlos-Castro, J., Zamudio-Abdala, J. H. \& Garduño-Trejo, J. (2012). Cognitive, Affective and Behavioral Components That Explain Attitude toward Statistics. Journal of Mathematics Research, 4(5).

Garcia, A., Garcia, F., Del Rey, A. M., Rodriguez, G. \& De La Villa, A. (2014). Changing assessment methods: New rules, new roles. [Article]. Journal of Symbolic Computation, 61-62, 70-84.

Geist, E. (2010). The Anti-Anxiety Curriculum: Combating Math Anxiety in the Classroom. Journal of Instructional Psychology, 37(1). 
GeoGebra (2014). Comunidad GeoGebra. Retrieved 23/05, 2014, from http://www. geogebra.org/cms/institutes

Gonzalez-Videgaray, M., Hernandez-Zamora, G. \& Del-Rio-Martinez, J. H. (2009). Learning objects in theory and practice: A vision from Mexican University teachers. Computers \& Education, 53(4), 13301338.

Grupo del Banco Mundial (2014). Usuarios de Internet (por cada 100 personas). Retrieved 19/05, 2014, from http://datos. bancomundial.org/indicador/IT.NET. USER.P2

Heckel, U., Bach, U., Richert, A. \& Jeschke, S. (2012). Massive Open Online Courses in Engineering Education: A novel approach to teaching large classes. 5th International Conference of Education, Research and Innovation (Iceri 2012), 2330-2339.

INEGI (2014). Mexican Data. Retrieved 21/05, 2014, from http://www3.inegi.org.mx/ sistemas/mexicocifras/grafica/grafica. $\operatorname{aspx}$ ? $=0 \&$ mun $=0$

Katz, I. R. (2013). Testing information literacy in digital environments: ETS's iSkills assessment. Information Technology and Libraries, 26(3), 3-12.

Kay, R. \& Kletskin, I. (2012). Evaluating the use of problem-based video podcasts to teach mathematics in higher education. Computers \& Education, 59(2), 619-627.

Koehn, P. (2010). Statistical Machine Translation. Cambridge, England: Cambridge University Press.
Kramarski, B. \& Hirsch, C. (2003). Using computer algebra systems in mathematical classrooms. [Article]. Journal of Computer Assisted Learning, 19(1), 35-45.

La Redaccion (2011). Será obligatorio el inglés en escuelas públicas en 2018: SEP. Retrieved 21/05, 2014, from http://www. proceso.com.mx/?p=275915

Lavicza, Z. \& Papp-Varga, Z. (2010). Integrating GeoGebra into IWB-equipped teaching environments: preliminary results. Technology Pedagogy and Education, 19(2), 245-252.

Lodha, S., Gunawardane, P., Middleton, E. \& Crow, B. (2009). Understanding relationships between global health indicators via visualisation and statistical analysis. Journal of International Development, 21(8), 1152-1166.

Lloyd, S. A. \& Robertson, C. L. (2012). Screencast Tutorials Enhance Student Learning of Statistics. Teaching of Psychology, 39(1), 67-71.

Marshall, N., Buteau, C., Jarvis, D. H. \& Lavicza, Z. (2012). Do mathematicians integrate computer algebra systems in university teaching? Comparing a literature review to an international survey study. Computers and Education, 58(1), 423-434.

Meece, J. L., Wigfield, A. \& Eccles, J. S. (1990). Predictors of math anxiety and its influence on young adolescents' course enrollment intentions and performance in mathematics. Journal of Educational Psychology, 82(1), 60 . 
MIT (2014). Open CourseWare. Retrieved 09/07, 2014, from http://ocw.mit.edu/index.htm

Mitra, S. \& Rana, V. (2001). Children and the Internet: Experiments with minimally invasive education in India. British Journal of Educational Technology, 32(2), 221-232.

$\mathrm{Ng}$, W. (2012). Can we teach digital natives digital literacy? Computers \& Education, 59(3), 1065-1078.

OECD (2013). Nota País-México. Retrieved 01/27, 2014, from http://www.oecd.org/ pisa/keyfindings/PISA-2012-results-mexico-ESP.pdf

OECD (2013). PISA 2012 Results. Retrieved 27/01, 2014, from http://www.oecd.org/ pisa/keyfindings/pisa-2012-results.htm

Onwuegbuzie, A. J. \& Wilson, V. A. (2003). Statistics Anxiety: Nature, etiology, antecedents, effects, and treatments-a comprehensive review of the literature. Teaching in Higher Education, 8(2), 195-209.

Open Society Institute (2002). Iniciativa de Budapest para el Acceso Abierto. Retrieved 04/25, 2009, from http://www.soros.org/ openaccess/esp/read.shtml

Parslow, G. R. (2012). Commentary: The Khan Academy and the day-night flipped classroom. Biochemistry and Molecular Biology Education, 40(5), 337-338.

Rath, J. \& Chung, C.J. (2013). Using Instructional Videos and Mobile Technology to Flip Your Classroom: A High School Teacher's Learning Journey and Best Practice. Paper presented at the Society for Information Technology \& Teacher Education International Conference.
Ray, D. L. (2013). Integrating Math \& Computer Skills in the Biology Classroom: An Example Using Spreadsheet Simulations to Teach Fundamental Sampling Concepts. American Biology Teacher, 75(7), 455460.

Reed, H. C., Drijvers, P. \& Kirschner, P. A. (2010). Effects of attitudes and behaviours on learning mathematics with computer tools. Computers \& Education, 55(1), 1-15.

Robertson, G., Fernandez, R., Fisher, D., Lee, B. \& Stasko, J. (2008). Effectiveness of Animation in Trend Visualization. Transactions on Visualization and Computer Graphics, 14(6), 1325-1332.

Rowlands, I., Nicholas, D., Williams, P., Huntington, P., Fieldhouse, M., Gunter, B., et al. (2008). The Google generation: the information behaviour of the researcher of the future. Paper presented at the Aslib Proceedings.

Schield, M. (2004). Information literacy, statistical literacy and data literacy. IASSIST Quarterly, 28(2/3), 6-11.

Shaffer, D. W. (2006). Epistemic frames for epistemic games. [Article]. Computers \& Education, 46(3), 223-234.

Siddique, Z., Ling, C., Roberson, P., Xu, Y. J. \& Geng, X. J. (2013). Facilitating Higher-Order Learning Through Computer Games. Journal of Mechanical Design, 135(12), 21004-21004.

Sosa, G. W., Berger, D. E., Saw, A. T. \& Mary, J. C. (2011). Effectiveness of Computer- 
Assisted Instruction in Statistics: A Meta-Analysis. Review of Educational Research, 81(1), 97-128.

Symanzik, J. \& Vukasinovic, N. (2003). Teaching experiences with a course on "Webbased statistics". American Statistician, 57(1), 46-50.

Taylor, M. J., Pountney, D. C. \& Baskett, M. (2008). Using animation to support the teaching of computer game development techniques. Computers \& Education, 50(4), 1258-1268.
Tucker, B. (2012). The flipped classroom. Education Next, 12(1), 82-83.

Tyteca, P. P., Parrilla, J. M. \& Martínez, E. C. (2013). Afecto y matemáticas. Diseño de una entrevista para acceder a los sentimientos de alumnos adolescentes. Avances de Investigación en Educación Matemática, 1(4), 65-82.

Zeidner, M. (1991). Statistics and mathematics anxiety in social science students: Some interesting parallels. British Journal of Educational Psychology, 61(3), 319-328. 